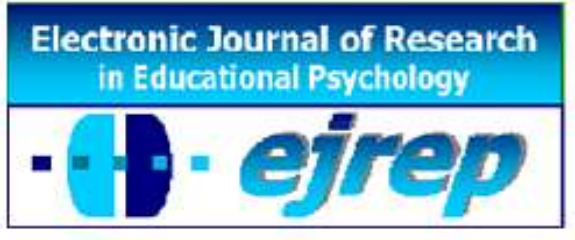

\title{
Pre-Service Teachers' Mindset Beliefs about Student Ability
}

\author{
C. Anne Gutshall
}

Teacher Education Department, College of Charleston.

\section{United States of America}

Correspondence: C. Anne Gutshall, College of Charleston, 66 George Street Charleston SC 29424 USA, e-mail: gutshalla@cofc.edu

(C) Education \& Psychology I+D+i and and Ilustre Colegio Oficial de la Psicología de Andalucía Oriental 


\section{Abstract}

Introduction. We all have beliefs about our ability or intelligence. The extent to which we believe ability is malleable (growth) or stable (fixed) is commonly referred to as our mindset. This research is designed to explore pre-service teachers' mindset beliefs as well as their beliefs when applied to hypothetical student scenarios.

Method. Pre-service teachers $(n=113)$ from a teacher preparation program were recruited to complete the mindset survey as well as a survey to measure their mindset beliefs given a hypothetical student scenario.

Results. Results suggest that pre-service teachers' mindset beliefs are overwhelmingly maleable (growth) and do not appear to change significantly from the beginning to the end of a teacher education program. However, mindset views for hypothetical student scenarios do appear amenable to influence and change from the beginning to the end of a teacher education program.

Discussion and Conclusion. Pre-service teachers likely enter their preparation programs with a mindset belief that is unlikely to change over the course of their studies; however, the practical applications of their mindset beliefs to students and classrooms may be amenable to influences from their teacher preparation programs.

Keywords: pre-service teachers, mindset beliefs 


\section{Creencias predispuestas de los futuros docentes sobre la capacidad de los alumnos Resumen}

Introducción. Todos tenemos creencias sobre nuestra capacidad o inteligencia. Esta investigación está diseñada para explorar las creencias sobre ellos mismos de los profesores en situación de pre-servicio. Específuicamente, respecto a sus creencias de amabilidad cuando se entretabn a escenarios de estudio complejos.

Método. Los profesores en formación $(n=113)$ de un programa de preparación de maestros fueron contratados para completar la encuesta de pensar, así como una encuesta para medir sus creencias mentalidad dado un escenario hipotético estudiante.

Resultados. Los resultados sugieren que las creencias de mentalidad de los profesores en formación "son abrumadoramente maleable" (en desarrollo) y no parecen cambiar significativamente desde el inicio hasta el final de un programa de formación docente. Sin embargo, los puntos de vista de mentalidad para los escenarios hipotéticos de los estudiantes parecen susceptibles de influir y cambiar desde el principio hasta el final de una formación docente programada.

Discusión y conclusiones. Los profesores en formación probablemente entran en sus programas de preparación con la creencia de pensar que pueden cambiar poco en el transcurso de sus estudios.Sin embargo, las aplicaciones prácticas de sus creencias mentales sobre los estudiantes y las situaciones en los salones de clase pueden ser susceptibles de ser influenciadas poe su profesor y los programas de formación.

Palabras Clave: profesores en formación, creencias mentalidad

Recepción: 27/03/14 Aceptación inicial: 12/04/14 Aceptación final: 25/10/14 


\section{Introduction}

One of the most researched areas regarding personal and epistemological beliefs are those related to the implicit beliefs we all hold regarding the permanence of our ability (Sternberg, Conway, Ketron, \& Bernstein, 1981) and whether or not it is 'malleable' or 'fixed' (Dweck \& Leggett, 1988; Dweck, 2006; Blackwell, Trzesniewski, \& Dweck, 2007). Those who believe overall ability can be improved or changed through effort and persistence tend to seek challenges, demonstrate effort and rebound from mistakes (Dweck, 2007). Whereas, those who believe ability is fixed tend to avoid making mistakes, believe that demonstrating effort signals low ability and recover poorly from setbacks (Dweck, 2007).

Researcher Carol Dweck (2007) refers to the theoretical construct outlining our implicit beliefs about the stability of ability as our "mindset" and argues that mindset can be measured between two ends of a spectrum ranging from fixed, or entirely stable to growth, or completely malleable. In Dweck's mindset self-assessment, respondents agree or disagree with a few statements such as" You have a certain amount of intelligence and you can't really do much to change it". Respondents' answers are measured on a scale of 1 to 6 . Over the past twenty-five years of research, these original terms (entity and incremental) have morphed into the routinely accepted terms: "fixed and growth mindset" (Dweck, 2006). Much of Dweck's research explores how our mindset impacts our motivation; however, in recent years research has expanded to consider how mindset might impact educational, occupational and personal experiences.

Research investigating teachers' theories about the nature of intelligence shows that individual views may impact instructional approaches (Swann \& Snyder, 1980). Teachers who were led to think that students' intelligence was fixed offered students less support. In contrast, when teachers believed that intelligence was malleable they provided increased support and reported instructional goals that explicitly taught students how to problem solve (Swann \& Snyder, 1980). Similar research outside of the educational field confirms that individual mindset may impact work with subordinates or mentees (Heslin, Vandewalle \& Latham, 2006). In the workplace, managers with a growth mindset were more likely to coach and help employees than were managers who believed that their subordinates' traits and abili- 
ties were fixed. Butler (2000) and Plaks, Stroener, Dweck and Sherman, (2001) measured the impact of implicit beliefs on the stability of ability as either fixed or growth for teachers and students. Results suggest that teachers holding malleable theories of intelligence tend to be more open to information about change over time. In sum, beliefs about mindset play a role in the amount of instructional support teachers offer students, which in turn is likely to have implications for student learning.

Researchers have offered a theoretical framework for how teachers' mindsets and student mindsets might interact in the higher education classroom setting (Yorke \& Knight, 2004) While purely theoretical, the researchers suggest that there may be four possible scenarios for the interactions between teacher mindset and student mindset including the following 4 pairings: Teacher malleable, Student malleable; Teacher malleable, Student fixed; Teacher fixed, Student malleable; and Teacher fixed, Student fixed. The implications of these possible pairings are yet to be explored empirically. Along similar theoretical lines, Dweck \& Bempechat (1983) hypothesized that teachers' personal implicit theories of ability may in fact be the manner in which children "get messages about the meanings of smartness" (p. 251)

Research conducted by Rattan, Good and Dweck (2012) was designed to explore the potential impacts of mindset on pedagogical practice that instructors might use when students demonstrate difficulty also suggests that mindset beliefs may impact pedagogical practice. Undergraduate students were placed in a teacher role and given scenarios describing students with low math ability. Those with a fixed mindset "were more likely to comfort students for their presumed low ability and to engage in pedagogical practices that could reduce engagement." (Rattan et al, 2012, p.5). Recently, research has sought to explore teachers' mindset beliefs and how these beliefs might be applied to hypothetical student abilities and disabilities (Gutshall, 2013). This research explored the relation between teachers' mindset beliefs and how these mindset beliefs applied to hypothetical student scenarios through the use of the Dweck mindset survey with 238 classroom teachers. Findings suggest that teachers' mindsets are related to teachers' mindsets applied to hypothetical student scenarios.

\section{The present study}

Research exploring pre-service teachers mindset beliefs and how these beliefs develop is unrepresented in the literature. This study seeks to investigate two questions: First, what 
are pre-service teachers' mindset beliefs and beliefs about ability applied to hypothetical student scenarios at the beginning of a teacher preparation program prior to formal education coursework? Second, what are pre-service teachers' mindset beliefs about student learning and beliefs applied hypothetical student scenarios at the end of a traditional teacher education preparatory program including a clinical practice experience commonly known as student teaching?

\section{Method}

\section{Participants}

Pre-service teachers $(n=113)$ were voluntarily recruited from either their Introduction to Education class $(n=55)$ or their final clinical practice meeting $(n=58)$. All participants were enrolled in a teacher education program in a mid-sized liberal arts college in the southeastern United States. The Introduction to Education class is typically the first course taken in the teacher education major. The final clinical practice meeting is the closing event for students who have successfully completed the 16 week student teaching experience which takes place at the very end of the teacher education program. Students across two full semesters were asked to voluntarily complete the survey or return a blank survey to the collection box. All students in the Introduction to Education class $(n=55)$ completed the survey. Whereas, two students from the final clinical practice group $(n=60)$ chose not to complete the survey. As such, 113 of 115 potential participants completed the survey.

Participants were selected during the same calendar year and thereby constituted a cross sectional sample of teacher education candidates at the beginning and end of the program of study. They were not the same students at the beginning and end of a teacher education program. The sample consisted of $67 \%$ female, $14 \%$ male and 19\% (no reported gender) college- aged students.

All pre-service teachers were administered a paper and pencil survey that included the three item mindset scale survey originally created by Dweck and Henderson (1989), used with permission by Carol Dweck and listed below. This measure has high internal consistency (alpha ranging from .94 to .98) and high test-retest reliability ( $r=.80, \mathrm{~N}=62)$. As noted by Hong, Chiu, Dweck, Lin and Wan (1999), 'only three items are included because the items are 
intended to have the same meaning and continued repetition of the same idea becomes somewhat bizarre and tedious to the respondents" (p. 590).

\begin{tabular}{|c|c|c|c|c|c|c|}
\hline $\begin{array}{l}\text { DIRECTIONS: People have different ideas } \\
\text { about intelligence and ability. Below are } \\
\text { statements that refer to views about intelli- } \\
\text { gence. Read each one carefully. There are no } \\
\text { right or wrong answers. }\end{array}$ & $\begin{array}{l}\text { Strongly } \\
\text { Disagree } \\
1\end{array}$ & $\begin{array}{c}\text { Disagree } \\
2\end{array}$ & $\begin{array}{l}\text { Sort of } \\
\text { Disagree } \\
3\end{array}$ & $\begin{array}{l}\text { Sort of } \\
\text { Agree } \\
4\end{array}$ & $\begin{array}{c}\text { Agree } \\
5\end{array}$ & $\begin{array}{c}\text { Strongly } \\
\text { Agree } \\
6\end{array}$ \\
\hline $\begin{array}{l}\text { You have a certain amount of intel- } \\
\text { ligence and you really cannot do } \\
\text { much to change it }\end{array}$ & & & & & & \\
\hline $\begin{array}{l}\text { Your intelligence is something } \\
\text { about you that you cannot change } \\
\text { very much }\end{array}$ & & & & & & \\
\hline $\begin{array}{l}\text { You can learn new things but you } \\
\text { cannot change your basic intelli- } \\
\text { gence }\end{array}$ & & & & & & \\
\hline
\end{tabular}

Two additional items were included but not scored in order to control for and relieve potential redundancy and/or boredom for the respondents (See Appendix A). All items were reverse scored with the most malleable mindset receiving a score of 6 and the most fixed mindset receiving a score of 1 . The percentage of teachers with a fixed mindset, growth mindset or no mindset was calculated using the method detailed in Dweck and Henderson (1989) where responses on the three items were averaged for a total mindset score. As described in Dweck and Henderson (1989) scores between 1 and 3 were scored as fixed mindset, scores between 3.1 and 3.9 were considered to have no clear mindset or neutral and scores between 4 and 6 were considered to be growth mindset scores.

Next, participants were also asked to read one of four student scenarios (Author, 2013) detailing a student who was struggling in school in specific areas (difficulty grasping main concepts and poor classroom assessment or poor classroom assessments and failing grades) but also had positive attributes (leader or eager and enthusiastic). In these scenarios, the students either had or had not been recently diagnosed with a learning disability (LD or No LD). Two students in the scenarios were male (Michael or Charlie) and the other two students were female (Michelle or Carly). The four scenarios included the following: (Male/LD), (Female/LD), (Male/no LD) and (Female/ No LD). The 4 different scenarios are detailed below. 
Next, after the scenario analysis, all participants were asked to rate the hypothetical students on the following 3 questions that were almost identical to the questions used to determine mindset. An additional non scored item was included. The example listed below is for the male, No LD scenario.

\begin{tabular}{|c|c|c|c|c|c|c|}
\hline $\begin{array}{l}\text { DIRECTIONS: People have different ideas } \\
\text { about intelligence and ability. Below are } \\
\text { statements that refer to views about intelli- } \\
\text { gence. Read each one carefully. There are no } \\
\text { right or wrong answers. }\end{array}$ & $\begin{array}{l}\text { Strongly } \\
\text { Disagree } \\
1\end{array}$ & $\begin{array}{c}\text { Disagree } \\
2\end{array}$ & $\begin{array}{c}\text { Sort of } \\
\text { Disagree } \\
3\end{array}$ & $\begin{array}{c}\text { Sort of } \\
\text { Agree } \\
4\end{array}$ & $\begin{array}{c}\text { Agree } \\
5\end{array}$ & $\begin{array}{c}\text { Strongly } \\
\text { Agree } \\
6\end{array}$ \\
\hline $\begin{array}{l}\text { Michael may be able to perform } \\
\text { better in school; however his real } \\
\text { ability will not change. }\end{array}$ & & & & & & \\
\hline $\begin{array}{l}\text { Because Michael has difficulties in } \\
\text { grasping the main concepts it will } \\
\text { be difficult for him to improve his } \\
\text { ability. }\end{array}$ & & & & & & \\
\hline $\begin{array}{l}\text { Michael will probably make pro- } \\
\text { gress in school but his overall abil- } \\
\text { ity and test scores will not change } \\
\text { much. }\end{array}$ & & & & & & \\
\hline
\end{tabular}

Finally, at the bottom of each of the four hypothetical scenarios, the following prompt was included"

"Please share any additional thoughts about Michael that you may have:"

The ratings on the given scenarios were calculated using the method specified by Dweck and Henderson (1989) wherein an average for the three mindset questions was tabulated. Once again, as described in Dweck and Henderson (1989) scores between 1 and 3 were scored as fixed mindset for scenario, scores between 3.1 and 3.9 were considered to have no 
clear mindset (neutral) for scenario and scores between 4 and 6 were considered to have growth mindset for scenario scores. Each participant was asked to complete the mindset survey and 1 of the 4 student scenarios. Post hoc comparisons between pre-service teachers' mindset for ability and their ratings of mindset related prompts given specific student scenarios were computed for the two groups of participants.

\section{Statistical Analysis}

Mindset scores for pre-service teachers at the beginning and end of their teacher education program were summed and averaged. As detailed in Dweck and Henderson (1989) scores between 1 and 3 were scored as fixed mindset, scores between 3.1 and 3.9 were considered to have no clear mindset or neutral mindset and scores between 4 and 6 were considered to have a growth mindset. In keeping with earlier work, it is expected that about $15 \%$ of the total population will demonstrate no clear mindset, or respond neutrally to the items presented. In the present sample, $10.9 \%$ of first semester pre- service teachers and $13.7 \%$ of post- clinical practice pre- service teachers demonstrated no clear mindset which will be referred to as "neutral mindset". Table 1 depicts the total frequencies and percentages for mindset for the two groups.

Table 1. Frequency and Percentage and Chi Square values of Growth, Neutral and Fixed Mindset Scores for Pre-Service Teachers in First Semester and Post Clinical Practice

\begin{tabular}{l|lll}
\hline & Growth Mindset & Neutral Mindset & Fixed Mindset \\
\hline $\begin{array}{l}\text { First Semes- } \\
\text { ter }(\mathrm{n}=55)\end{array}$ & $40(72.70 \%)$ & $6(10.90 \%)$ & $9(16.30 \%)$ \\
$\begin{array}{l}\text { Post Clinical } \\
(\mathrm{n}=58)\end{array}$ & $44(75.80 \%)$ & $8(13.70 \%)$ & $6(10.30 \%)$ \\
$\begin{array}{l}\text { Yates Chi } \\
\text { Square }\end{array}$ & $\mathrm{X} 2=.0, \mathrm{df}=1, \mathrm{p}=1.0$ & $\mathrm{X} 2=.02, \mathrm{df}=1, \mathrm{p}=.88$ & $\mathrm{X} 2=.30, \mathrm{df}=1, \mathrm{p}=.58$ \\
\hline
\end{tabular}

Significant differences in proportions were evaluated using a Yates Chi Square nonparametric statistical test for the three mindset categories. As depicted in Table 1, the following chi square results were calculated for the groups: Growth $\operatorname{Mind} \operatorname{set}(\{\mathrm{x} 2,1$, $113\}=.0, \mathrm{p}=1.0) ; \quad$ Neutral Mindset $(\{\mathrm{x} 2,1,113\}=.02, \mathrm{p}=.88) ; \quad$ and Fixed Mindset $(\{\mathrm{x} 2,1,113\}=.30, \mathrm{p}=.58)$. None of the groups were significantly different. That is, pre- service teachers in the first semester prior to taking education courses and pre-service teachers at the 
end their formal classwork including 16 weeks of clinical practice demonstrated the same percentages of growth, neutral and fixed mindset with the vast majority (74\%) of respondents endorsing a growth mindset.

Next, mindset scores were tabulated for the four different hypothetical student scenarios including: Male Learning Disabled (Male LD); Female Learning Disabled (Female LD); Male No Learning Disability (Male No LD) and Female No Learning Disability (Female No LD). Chi Square values were once again calculated and there were no significant differences between any of the four categories. As shown in Table 2, pre-service teachers' mindset views applied to hypothetical scenarios were not significantly impacted by either the gender or the disability status of the hypothetical student as determined by chi square calculations for Growth Mindset, Neutral Mindset, and Fixed Mindset for each of the four hypothetical scenarios.

Table 2. Frequency and Chi Square Values of Growth, Neutral and Fixed mindset scores for hypothetical student scenarios for first semester and post clinical practice pre- service teacher by gender and disability status of hypothetical student

\begin{tabular}{|c|c|c|}
\hline & $\begin{array}{l}\text { First Semester } \\
(\mathrm{n}=55)\end{array}$ & $\begin{array}{l}\text { Post Clinical } \\
(\mathrm{n}=58)\end{array}$ \\
\hline Male LD & $(\mathrm{n}=14)$ & $(n=14)$ \\
\hline Growth Mindset & 10 & 10 \\
\hline Neutral Mindset & 2 & 4 \\
\hline Fixed Mindset & 2 & 0 \\
\hline Female LD & $(n=14)$ & $(n=14)$ \\
\hline Growth Mindset & 8 & 14 \\
\hline Neutral Mindset & 3 & 0 \\
\hline Fixed Mindset & 3 & 0 \\
\hline Male NO LD & $(n=14)$ & $(n=15)$ \\
\hline Growth Mindset & 12 & 13 \\
\hline Neutral Mindset & 1 & 2 \\
\hline Fixed Mindset & 1 & 0 \\
\hline Chi Square Values & $\begin{array}{l}\text { Growth Mindset } \\
x 2=.56, \mathrm{df}=3 \\
\mathrm{p}=.90 \\
\text { Neutral Mindset } \\
x 2=.15, \mathrm{df}=1, \\
\mathrm{p}=.69 \\
\text { Fixed Mindset } \\
X 2=.15, \mathrm{df}=1, \\
\mathrm{p}=.69\end{array}$ & $\begin{array}{l}\text { Growth Mindset } \\
X 2=0, d f=1, \\
p=1.0 \\
\text { Neutral Mindset } \\
X 2=.23, d f=1, \\
p=.63 \\
\text { Fixed Mindset } \\
X 2=0, \\
d f=1, p=1.0\end{array}$ \\
\hline
\end{tabular}




\section{Results}

Since there were no discernible differences among first semester pre- service teachers' ratings for the varying genders or disabilities of the hypothetical students in the scenarios and post clinical practice pre-services teachers' ratings for the varying genders and disability combinations, scenario mindset values for all four scenarios were combined and evaluated as a group (referred to hereafter as mindset for scenarios). Differences between the first semester pre- service teachers and the clinical practice group for mindset for scenarios were explored. As depicted in Table 3, the following frequencies and percentages for mindset for scenarios were found for first semester pre-service teachers: Growth Mindset $(36 / 55)=65.5 \%$; Neutral Mindset $(9 / 55)=16.3 \%$ and Fixed Mindset $(10 / 55=18.2 \%)$ and post clinical practice pre-service teachers: Growth Mindset (48/58)=82.8\%; Neutral Mindset (9/55)=16.3\%; Fixed Mindset $(0 / 58)=0.0 \%$. Once again chi square values were computed to determine the significance between the two groups. As noted in Table 3 the following values were found for Growth Mindset $[\mathrm{x} 2,1,113\}=.44, \mathrm{p}=.51 ;$ Neutral Mindset $\{\mathrm{x} 2,1,113\}=.02, \mathrm{p}=.89 ;$ and Fixed Mindset $\{\mathrm{x} 2,1,113\}=7.76, \mathrm{p}=.00 * * *$. Only the fixed mindset group was determined to be unexpected, or significantly different.

Table 3. Frequency, Percentage and Chi Square values of Growth, Neutral and Fixed Mindset for Scenario scores for first semester and post clinical practice pre- service teachers

\begin{tabular}{l|ccc}
\hline & Growth & Neutral & Fixed \\
\hline First Semester & $36(65.5 \%)$ & $9(16.3 \%)$ & $10(18.2 \%)$ \\
$(\mathrm{n}=55)$ & & & \\
& & & \\
Post Clinical & $48(82.8 \%)$ & $10(17.2 \%)$ & $0(0.0 \%)$ \\
$(\mathrm{n}=58)$ & $\mathrm{X} 2=.44$, & $\mathrm{X} 2=.02, \mathrm{df}=1$, & $\mathrm{X} 2=7.76, \mathrm{df}=1$, \\
& $\mathrm{df}=1, \mathrm{p}=.51$ & $\mathrm{p}=.89$ & $\mathrm{p}=.00 * * *$ \\
Chi Square & & & \\
Values & & & \\
\hline
\end{tabular}


While the Growth Mindset and Neutral Mindset responses were not significantly different, comparisons between the Fixed Mindset proportions revealed that the differences between the two groups was significant. Stated differently, pre-service teachers in their first semester of study espoused significantly more Fixed Mindset views (18.2\%) for hypothetical student scenarios than did their more experienced peers who had just completed their 16 week clinical practice or student teaching experience and all teacher education coursework. This group demonstrated no fixed mindset scores for hypothetical students. As depicted in Figure 1, not one of the 58 pre-service teachers surveyed scored in the Fixed Mindset range for a single hypothetical student scenario.

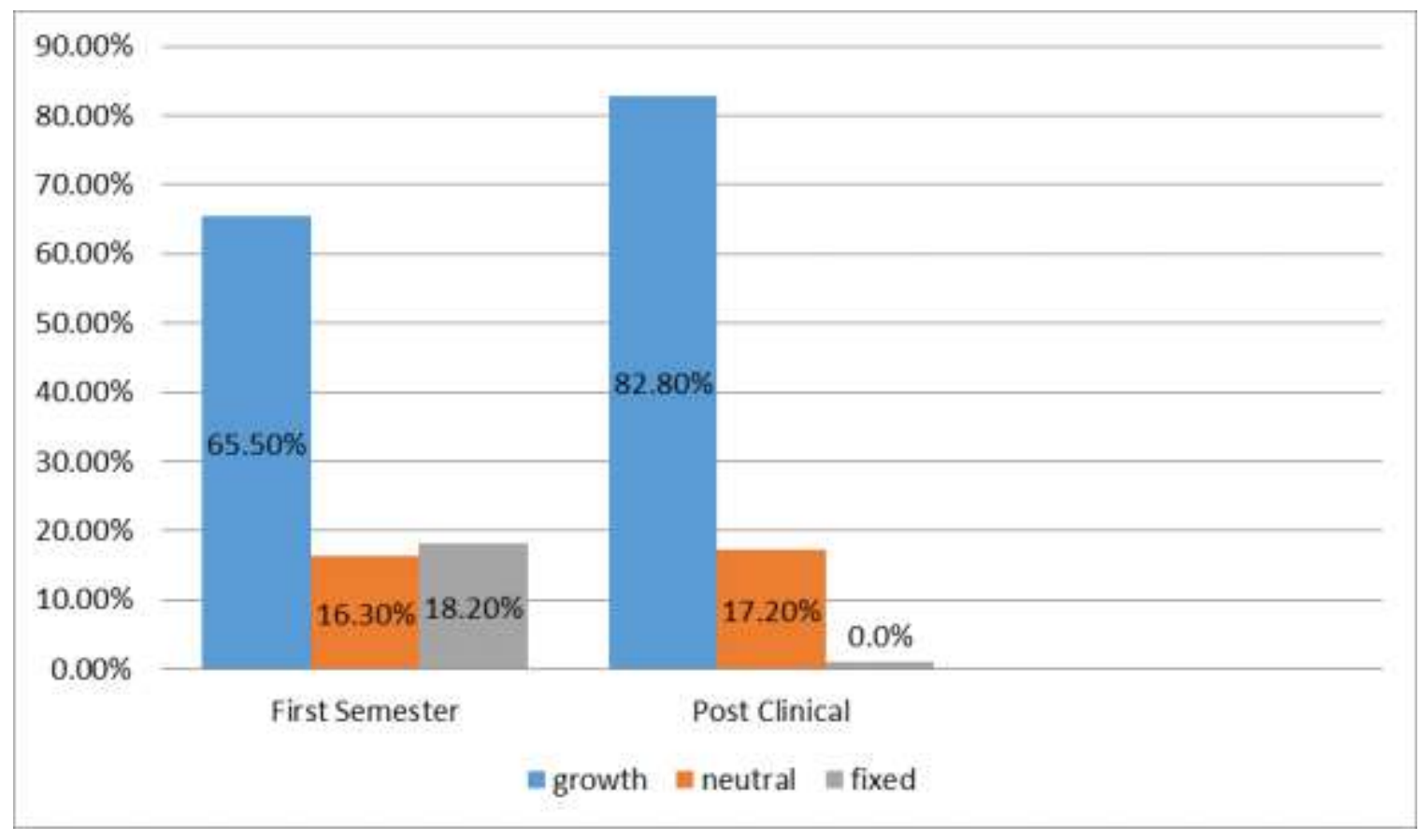

Figure 1 . Scenario Mindset for First Semester and Post Clinical Practice

\section{Post-hoc Content Analysis of Informal Comments}

In addition to completing the mindset surveys, a number of the participants also responded to the prompt inviting them to share additional thoughts about the hypothetical student. More specifically, of the Introduction to Education students, 3 of the 55 shared additional thoughts in writing; whereas, of the post-clinical practice students, 17 of the 58 shared additional written thoughts. Overall, participants were far more likely to write their thoughts 
at the end of the formal teacher education program $(n=17)$ than they were in the beginning of the program $(n=3)$.

Informal content analysis of the pre service teachers' comments was reflective of their emerging understandings of the hypothetical student scenarios. More specifically, as novices in their teacher education program, the three first semester students' comments included the following: "he needs to practice more, practice makes perfect, "needs a new learning style" and "I think he will learn better if interested in the subject." In contrast, pre- service teachers at the end of their clinical practice (student teaching) experience tended to share comments that reflected their developing growth mindset beliefs for students and their emerging understandings regarding the malleability of student ability including the following: "grasping main concepts may be difficult, but not impossible", "Charlie's ability can change with effective teaching motivation and engagement", "Any child can learn if you give them time, opportunity and a chance" and "It will take time and a lot of effort but Michael can improve he just needs people who are willing to work with him and believe in him".

\section{Discussion and Conclusions}

Pre-service teachers at the beginning and at the end of a traditional teacher preparation program demonstrated predominantly growth mindset beliefs (mean=73\%) with respect to the malleability of intelligence. Moreover, findings suggest that mindset, or beliefs regarding the stability/malleability of intelligence, is a stable construct for pre-service teachers and participants responded similarly whether at the beginning or the end of teacher preparation program. However, fixed mindset beliefs applied to hypothetical student scenarios do appear to detect differences in mindset beliefs when comparing students at the beginning and at the end of a typical teacher education program. More specifically, pre-service teachers at the end of their program are much less likely to espouse a fixed mindset belief when presented with a student scenario than they are to endorse a fixed mindset belief for mindset without a student scenario, independent of hypothetical student gender or disability status.

However, these findings do not appear to be true for pre- service teachers at the very beginning of their teacher education program. Rather, their ratings for mindset and mindset applied to hypothetical student scenarios were about the same suggesting that trends away 
from fixed mindset beliefs for hypothetical students may take place sometime during teacher education coursework and or clinical practice or student teaching experiences.

Informal analysis of pre-service teachers' free response comments proved to be enlightening. While both introduction level and clinical practice level teachers tended to write very positive comments regarding the students depicted in the hypothetical scenarios, there seemed to be a subtle shift in the comments written by pre-service teachers who had completed the clinical practice (student teaching). The shift observed was a move from unspecified support of the hypothetical student to a focus on the need for teachers to support and assist the hypothetical student. More specifically, a typical introductory level student comment included the following: "I think he will learn better if interested in the subject." Whereas, pre- service teachers at the end of clinical practice tended to write teacher focused comments such as, "Charlie's ability can change with effective teaching motivation and engagement".

The pre-service teachers' comments may serve as a clue as to why the significant decrease in fixed mindset scores was observed for hypothetical scenarios in the Clinical Practice group. One hypothesis is that pre -service teachers found a growing sense of self -efficacy as a result of their clinical practice experiences. That is, consistent with previous research (Gibson \& Dembo, 1984; Gurvitch \& Metzler, 2009) pre-service teachers at the end of their teacher preparation program appeared to have developed the belief that they are a key determining factor in a child's success in the classroom, or increased teacher self -efficacy as a result of their field based experiences. Moreover, pre-service teachers' experiences in practice with actual children combined with their coursework may have initiated and supported the change in pre-service teachers' mindset beliefs for applied hypothetical student scenarios over the course of their teacher education program.

It is likely that pre- service teachers enter teacher education programs with a variety of beliefs regarding teaching and learning (Zeichner \& Listor, 1987). Seminal research on implicit personal beliefs regarding ability has focused on the epistemological theories we all hold regarding the extent to which our own ability is fixed or malleable (Dweck, 2007). More recently, research has sought to understand how teachers' beliefs regarding ability might influence their practice (Rattan et al, 2012). Research highlighted in this study seeks to build upon extant evidence investigating the nature of pre-service teachers' mindset beliefs during 
their first semester of a teacher education program and again at the end of student teaching, or clinical practice. Consistent with previous research (Hollingsworth, 1989; Gitlin, e.t al, 1999; Gill, et. al, 2004) this study provides evidence that pre-service teachers' mindset beliefs are similar to practicing teachers and stable over the course of their program of study. However, findings suggest there may be a change in pre-service teachers' mindset beliefs when applied to hypothetical students sometime after their first education class and at the end of their clinical practice, or student teaching experience. It is possible that pre-service teachers' experiences in clinical practice (student teaching) with actual students as well as their coursework are likely to be a major contributing factor in their change in mindset beliefs applied to student scenarios. Building upon the theoretical findings cited in Gill et al (2004) it could be that mindset is a domain general epistemological belief; whereas, mindset applied to hypothetical students is a domain specific belief and therefore more amenable to change.

For now, educators working to prepare pre- service teachers as well as those working with novice teachers in schools may want to understand more clearly the mindset beliefs of pre- service teachers prior to their formal coursework and experience. They may also want to consider that while mindset beliefs about ability appear to be very stable, there does appear to be a difference when it comes to applying fixed mindset beliefs about ability in practice with students wherein the types of experiences that may influence pre- service teachers' applied beliefs will be important in understanding this finding. Careful understanding of the subtle nuances and implications of teacher beliefs about student ability and how they might be influenced by experiences and practice with actual students in classrooms is essential as beliefs in and of themselves may be less reliable and valid compared to the classroom and practical application of beliefs.

\section{References}

Blackwell, L., Trezesniewski, K., \& Dweck, C. (2007). Implicit theories of intelligence predict achievement across an adolescent transition: A longitudinal study and an inter vention. Child Development, 78(1), 246-263.

Butler, R. (2000). Making judgments about ability: The role of implicit theories of ability in moderating inferences from temporal and social comparison information. Journal of Personality and Social Psychology, 78(5), 965-978. 
Dweck, C. (2006). Mindset: The new psychology of success. New York: Ballantine Books.

Dweck, C. (2007). Messages that motivate and boost achievement. Education Canada, Spring, 6-10.

Dweck C., \& Bempechat, J. (1983). Children's theories of intelligence learning. In Paris, Olson and Stevenson (Eds.), Learning and motivation in the classroom (pp. 239-256). London: Erlbaum Associates.

Dweck, C., \& Henderson, V. (1989, April). Theories of intelligence: Background and measures. Paper presented at the Biennial Meeting of the Society for Research in Child Development, Kansas, MO (ERIC Document Reproduction Service No.ED 312 057).

Dweck, C., \& Leggett, E. (1988). A social-cognitive approach to motivation and personality. Psychological Review, 95(2), 256-273.

Gibson, S., \& Dembo, M. (1984). Teacher efficacy: A construct validation. Journal of Educational Psychology, 76(4), 569-582.

Gill, M., Ashton, P., \& Algina, J. (2004). Changing preservice teachers' epistemological beliefs about teaching and learning in mathematics: An intervention study. Contemporary Educational Psychology, 29, 164-185.

Gitlan, A., Barlow, L., Burbank, M., Kauchak, D, \& Stevens, T. (1999). Pre-service teachers' thinking on research: Implications for inquiry oriented teacher education. Teaching and Teacher Education, 15, 753-769.

Gutshall, C.A. (2013). Teachers' mindsets for students with and without disabilities. Psychology in the Schools, 51(10), 1073-1083,doi:10.1002/pits.21725.

Gurvitch, R. \& Metzler, M. (2009). The effects of laboratory-based and field based practicum experience on pre-service teachers' self-efficacy. Teaching and Teacher Education, 25,437-443.

Heslin,P., Vandewalle, D.,\& Latham, G. (2006). Keen to help? Managers' implicit person theories and their subsequent employee coaching. Personnel Psychology, 59, 871-902.

Hollingsworth, S. (1989). Prior beliefs and cognitive change in learning to teach. American Educational Research Journal, 26, 160-189.

Hong, Y., Chiu, C., Dweck, C., Lin, D., \& Wan, W. (1999). Implicit theories, attributions, and coping: A meaning system approach. Journal of Personality and Social Psychology, 77(3), 588-599.

Kaya, S., Lundeen, C. \& Wolfgang, C. (2010). Discipline orientations of pre-service teachers before and after student teaching. Teaching Education, 21(2), 157-169. 
Plaks, J.E., Stroessner, S.J., Dweck, C., \& Sherman, J.W. (2001). Person theories and Attention allocation: Preferences for stereotypic versus counter stereotypic information. Journal of Personality and Social Psychology, 80, 876-893.

Rattan, A., Good, C., \& Dweck, C. (2012). It's ok-not everyone can be good at math: Instructors with an entity theory comfort (and de-motivate) students. Journal of Experimental Social Psychology,48 (3). doi:10.1016/j.jesp.2011.12.012.

Sternberg, R., Conway, B., Ketron, J., \& Berstein, M. (1981). People’s conceptions of intelligence. Journal of Personality and Social Psychology, 41(1), 37-55.

Swann, W., \& Snyder, M. (1980). On translating beliefs into action: Theories of ability and Yorke, M., \& Knight, P. (2004). Self-theories: Some implications for teaching and learning in higher education. Studies in Higher Education, 29(1), 25-37.

Zeichner, K., \& Liston, D. (1987). Teaching student teachers to reflect. Harvard Educational Review, 57(1), 23-48. 


\section{Appendix A}

Male or Female (circle)

People have different ideas about intelligence and ability. Below are statements that refer to views about intelligence. Read each one carefully. There are no right or wrong answers.

$\begin{array}{cccccc}\text { STRONGLY } & \text { DISAGREE } & \text { SORT OF } & \text { SORT OF AGREE } & \text { AGREE } & \text { STRONGLY } \\ \text { DISAGREE } & \text { DISAGREE } & \text { AGREE } \\ 1 & 2 & 3 & 4 & 5 & 6\end{array}$

You have a certain amount of intelligence and you really cannot do much to change it.

1 2 3

4

5

6

I see strengths and weaknesses (limitations) in each individual.

1 2

3

4

5

6

Your intelligence is something about you that you cannot change very much.

1

2

3

4

5

6

I believe learning takes time.

1 2 3

4 5 6

You can learn new things but you cannot really change your basic intelligence. 